\title{
The Importance of Delegation of Authority, Budget Allocation and Leadership in Improving Performance
}

\author{
Jujun Juhana ${ }^{1}$, Sadu Wasistiono ${ }^{2}$, Irwan Tahir ${ }^{3}$, Kusworo ${ }^{4}$ \\ ${ }_{1,2,3,4}$ Institut Pemerintahan Dalam Negeri (IPDN), Indonesia \\ Email: jujun.juhana@gmail.com
}

\begin{abstract}
This study discusses the influence of delegation of authority, budget allocation and leadership to the performance of sub-districts in Garut Regency, West Java Province, Indonesia. This research uses a quantitative approach by collecting data in the form of questionnaires to respondents. The number of samples taken in this study was 286 respondents from a total population of 1003 people with a stratified random sampling technique. Data analysis techniques using SEM analysis. Based on the results of the study note that the delegation of authority, budget allocation, and leadership has a positive and significant effect on the performance of districts in Garut Regency, both partially and simultaneously.
\end{abstract}

Keywords: Delegation of Authority, Budget Allocation, Leadership, Performance.

\section{A. INTRODUCTION}

Each Regional Apparatus Work Unit (WRU), including the District Office, has certain authority to carry out the duties and functions of the organization. Authority is defined as the right to act or to order others to act, towards the achievement of organizational goals (Stoner \& Wankel, 1996, Kaho, 2002; Robbins, 1994). In the view of the modern organization put forward by Weber (in Sutarto, 1995), the ideal type of organization is characterized by a hierarchy or delegation of authority, clear division of tasks, work rules or procedures as well as personnel qualifications.

Delegation is the process of handing over work to subordinates. Jobs submitted are jobs that fall within the area of responsibility of a manager. The final responsibility still lies with the manager, and in his turn, he will still be held responsible by his higher superiors (Ndraha, 2011; Kaho, 2002). Meanwhile, power itself is the ability that makes a person or others to do or not do something as they wish (Wasistiono, 2004; Terry, 1960; Strauss \& Corbin, 2007).

Delegation of authority is not just about transferring authority but in order to improve the effectiveness and efficiency of services to the community and the use of public funds and facilities for the public benefit. In addition, the delegation of authority must be able to fulfill and enhance a sense of community justice, including obtaining equal facilities and access, especially for groups of people who have been marginalized. On the other hand, a delegation of authority must be able to be a lever of community 
economic activities so that they become more productive. Delegation of authority should not extend the level of bureaucracy and create a high-cost economy that makes people unproductive and unable to compete with foreign countries.

If the delegation of authority in question is related to the administration of the government system, the delegation or delegation of authority is included in the implementation of the decentralization and regional autonomy policies. For example, the delegation or delegation of authority from the Regional Head to the District Head to carry out certain government affairs, which is considered more effective or more efficient when carried out by the District Head and the sub-district apparatus. The delegation of authority in question can be related to the administration of public services that are monopolized by the State such as licensing services; and can also be related to the administration of other governmental affairs which are the obligations of each region. Such authority delegation seems to have also taken place in the administration of the Regional Government of Garut Regency.

According to Wasistiono (2001), to carry out the authority of regents/mayors who have been delegated to the camat, budget support is needed. In addition, in order to exercise the authority that has been delegated to him, the camat needs sufficient personnel support. Furthermore, to exercise authority that has been delegated to him, the camat needs logistical support. The quantity and quality of logistics provided to the sub-district head are adjusted to the level of need determined by the typology.

With such a policy on administering the sub-district government, increasing the performance of the sub-district in the Garut Regency is very important because there are a number of weaknesses and shortcomings that cause sub-district performance to be not optimal. The sub-district performance in Garut Regency is not yet optimally suspected to be influenced by several factors, including the delegation of authority, budget allocation, and leadership. Based on the description above, the purpose of this study is to analyze the influence of delegation of authority, budget allocation and leadership to the performance of sub-districts in Garut Regency, Indonesia.

\section{B. Literature ReVIEW}

Sub-district performance is not yet optimal seems to be a phenomenon of public service performance that correlates with various variables. Among a number of variables that correlate or influence, it is assumed that the delegation of authority, budget allocation, and leadership are the three variables that have a positive (direct) influence on the performance of the sub-district.

The assumption stating that delegation of authority influences the performance of sub-districts is the opinion of Handoko (in Kaho, 2002) which says that in the process of delegation of authority there are four activities that take place respectively: 1) Delegation establishes and provides goals and tasks to subordinates; 2) Delegating delegates the authority needed to achieve the goals and tasks; 3) Recipient of the 
delegation, whether implicitly or explicitly giving rise to an obligation or responsibility; 4) The delegator accepts the responsibility of subordinates for the results achieved.

With the support of this opinion, the next variable Delegation of Authority is seen as the transfer of government authority from the Regent of Garut to the Head of District which is stated with the Regent's political desire to delegate part of the authority of the government to the Head of District, the Regent's political will to make the sub-district as the center of community service, regional technical institutions delegation to delegate some technical authority that can be exercised by the Camat, and budget and personnel support to carry out the delegated authority.

This view absorbs the theory of delegation of authority from Wasistiono, (2004) which says that the delegation of some government authority from the Regent / Mayor to the District Head can be carried out if it fulfills the following four prerequisites: 1) The political will of the Regent / Mayor to delegate part of the government authority to the District; 2) There are political parties and Regents / Mayors and Regency / City DPRDs to make sub-districts as centers of community service for types of services that are easy, cheap, and fast; 3) There is relegation from the department and or Lemtekda (regional technical institutions) to delegate a portion of the technical authority that can be exercised by the Camat, through the decision of the Regional Head; and 4) There are budget and personnel support to carry out delegated authority.

The assumption stating that the Budget Allocation affects Subdistrict Performance refers to the opinion of Suparmoko (2000), who said that the budget is basically a system for preparing and managing regional budgets that are oriented towards achieving results or performance. The performance must reflect the efficiency and effectiveness of public services, which means it must be oriented to the public interest. It is the need of regional communities to carry out broad, real and responsible autonomy and regional autonomy must be understood as the right or authority of local communities to manage and manage their own affairs. The aspect or role of the regional government is no longer a mere tool of the interests of the central government but rather a tool to fight for regional aspirations and interests.

The assumption stating that leadership influences the performance of subdistricts refers to Budiman's opinion (in Simorangkir, 2004) which says that leadership is an art to encourage the performance and motivation of organizational resources towards achieving organizational goals, vision, and mission. In this view, Budiman said, "leadership as an art encourages others to do what the leader wants them to do". Art is an effort of how a leader to encourage others to do something they want.

With the support of this opinion, then the Leadership variable is seen as a series of social interactions between the Sub-District Head and the Sub-District Apparatus that takes place in carrying out the tasks and functions of the Sub-District Office which are revealed from the guidance and direction given by the Sub-District Head, the behavior of the Sub-District Head's relationship with the Sub-District Apparatus, and the level of 
device readiness sub-district. This view absorbs the situational leadership theory from Hersey \& Blanchard (1995) which says that situational leadership is based on the relationship between (1) the level of guidance and direction (task behavior) provided by the leader; (2) the level of socio-emotional support (relationship behavior) provided by the leader and (3) the level of readiness shown by followers in carrying out certain tasks, functions, or goals.

Based on performance theory, Prawirosentono (1997) said that Organizational performance is the appearance of a work process in the organization which includes the behavior of the actors (superiors and subordinates, employees/workers), work processes and work results achieved, then the District Performance variable is conceptualized as organizational performance The Sub-District Office in carrying out the tasks and functions of the sub-district which are revealed from the relationship between superiors and subordinates in carrying out the work; the process of work carried out, and the results of work achieved.

Based on the description above, the theoretical hypotheses of this study are as follows:

1. The magnitude of the influence of the Delegation of Authority on Subdistrict Performance is determined by the Regent's political will to delegate part of the authority of the government to the Camat, the Regent's political will to make the sub-district the center of community service, the regional technical institutions' delegation to delegate a part of the technical authority that can be carried out by the Camat, and personnel to exercise delegated authority.

2. The magnitude of the influence of the Budget Allocation on District Performance is determined by Comprehensive and Discipline, Flexibility, Predictability, Honesty, Information, Transparency, and Accountability.

3. The magnitude of the influence of leadership on the performance of the subdistrict is determined by the guidance and direction given by the sub-district head, the behavior of the sub-district head's relationship with the sub-district apparatus, the level of readiness of the sub-district apparatus.

\section{Method}

This research uses a quantitative approach (William, 2007; Yusuf, 2016; Sugiyono, 2017). The number of variables examined in this study consisted of 4 variables, namely the delegation of authority as the first independent variable (X1), budget allocation as the second independent variable (X2), leadership as the third independent variable (X3), and the performance of the district as the dependent variable (Y).

The data collection technique used in this study was the distribution of questionnaires to 286 respondents drawn from 1003 populations using the stratified random sampling technique (Cochran, 2007). Data obtained through the distribution of questionnaires were then processed and analyzed in accordance with the stated 
research objectives. In this study, the analytical method used is quantitative analysis with Structural Equation Modeling (SEM) with Amos 9.0 Software. Structural Equation Model (SEM) is a statistical technique whose processing simultaneously involves measurement errors, indicator variables, and latent variables. Latent variables are variables that cannot be measured directly so that these variables are formed or explained by indicator variables (observable variables) (Bachrudin \& Tobing, 2003; Ghozali, 2006).

\section{RESULT AND Discussion}

\section{Analysis of the Effect of Delegation of Authority on District Performance in Garut Regency}

The magnitude of the influence of the Delegation of Authority on the Performance of Districts in Garut Regency reached 0.754, included in the strong and significant category. The magnitude of the influence of the Delegation of Authority on the Performance of the District is determined by the Regent's political will to delegate part of the government's authority to the Camat, the Regent's political will to make the sub-district the center of community service, the regional technical institute's authority to delegate some technical authority that can be exercised by the Camat, budget support, and personnel to exercise delegated authority. The existence of such influence shows that between the Submission of Authority and Sub-District Performance a meaningful causal relationship is formed: if the Submission of Authority is increased or increased, the stimulant increase in the Submission of Authority is followed by an increase in Sub-District Performance. Therefore, increasing the performance of subdistricts in the Garut Regency can be improved by increasing, improving, optimizing 12 indicators of authority delegation.

The twelve indicators of Delegation of Authority referred to are the following: (1) Authority in the field of coordination, (2) Authority in the field of supervision, (3) Authority in the area of licensing, (4) Licensing services, (5) Educational services, (6) Services health, (7) Technical planning of physical work, (8) Technical implementation of physical work, (9) Technical supervision of physical work, (10) Support for performance budget allocation, (11) Support for activity budget allocation, (12) Support for apparatus resources.

The optimization of the Regent's delegation of authority to the District Head is carried out by optimizing support for the performance budget allocation, supporting the activity budget allocation, and supporting apparatus resources. The optimization of resource support is carried out in order to make the Camat as the middle manager of the government whose role is to optimize the relationship between the Regional Head and the Village Head in implementing the policy of decentralization and regional autonomy in Garut Regency. 


\section{Analysis of the Effect of Budget Allocation on District Performance in Garut District}

The magnitude of the influence of the Budget Allocation on District Performance in Garut Regency reached 0.651, included in the strong and significant category. The magnitude of the influence of the Budget Allocation on District Performance is determined by comprehensive and disciplined, flexibility, predictability, honesty, information, transparency, and accountability. The existence of such influence shows that between the Budget Allocation and the performance of the sub-district a meaningful causal relationship is formed: if the Budget Allocation is increased or increased the stimulant increase in the Budget Allocation is followed by an increase in the sub-districts performance. Therefore, improving the performance of sub-districts in the Garut Regency can be improved by increasing, improving, optimizing 18 Budget Allocation indicators.

The eighteen Budget Allocation indicators referred to are as follows: (1) comprehensive budget allocation, (2) accuracy of budget allocation, (3) discipline of budget allocation, (4) flexibility of budget allocation planning, (5) flexibility in implementing budget allocation, (6) flexibility in administering the budget allocation, (7) prediction of budget allocation performance indicators, (8) prediction of budget performance achievement indicators, (9) prediction of budget allocation optimization, (10) honesty in budget allocation planning, (11) honesty in using budget allocation, (12) honesty in reporting budget use, (13) budget allocation information management, (14) budget allocation information provision, (15) budget allocation information service, (16) transparency of budget allocation distribution, (17) transparency in the use of budget allocation, and (18) accountability for the use of budget allocations.

With the dynamics of such performance relationships, accountability for the use of sub-district budget allocations should be improved by increasing accountability for the use of sub-district budget allocations. This increase aims to improve the performance of sub-district budgets in the Garut Regency to increase transparency and accountability in the performance of various government policies, programs and activities, development, community empowerment, and public services at the subdistrict and village and village levels.

Improving the performance of sub-district budget allocations needs to be institutionalized into the Sub-District E-Budgeting System which is applied to the entire Regional Government Organization performance network and easily accessible to the community. Improving the performance of such sub-district budget allocations supports the realization of the sub-district E-Budgeting System as an integral part of EGovernment applications in Garut Regency. 


\section{Analysis of the Effect of Leadership on District Performance in Garut Regency}

The magnitude of the influence of Leadership on District Performance in Garut Regency reached 0.655 , included in the strong and significant category. The magnitude of the influence of leadership on the performance of the sub-district is determined by the guidance and direction given by the sub-district head, the behavior of the subdistrict head's relationship with the sub-district apparatus, and the level of readiness of the sub-district apparatus. The existence of such influence shows that between the Leadership and District Performance a meaningful causal relationship is formed: if the Leadership is improved or increased, the stimulant increase in Leadership is followed by an increase in Kecamatan Performance. Therefore, increasing the performance of sub-districts in the Garut Regency can be improved by increasing, improving, optimizing 12 leadership indicators.

The twelve indicators of Leadership referred to are the following: (1) Camat Guidance to sub-district leaders, (2) Camat Guidance to sub-district staff, (3) Camat Directives in policy implementation, (4) Camat Directives in implementing activities, (5) Camat Relations with sub-district leadership, (6) Sub-District Relations with sub-district staff, (7) Sub-district leadership, (8) Sub-district staff relations, (9) Sub-district manager readiness, (10) Sub-district government readiness, (11) Readiness of each sub-district section, and (12) Sub-district staff readiness.

Camat's guidance and direction; the Camat's relationship with the sub-district apparatus; and the readiness of the sub-district staff needs to be improved so that they become a reinforcing factor in the leadership of the government bureaucracy. Such an increase in government bureaucratic leadership can increase the effectiveness of government leadership at the sub-district level. Increasing the effectiveness of government leaders can have a positive effect on the effectiveness of the leadership of the village and village bureaucracy in the Garut Regency.

\section{E. Conclusion}

Based on the results of the study note that the delegation of authority, budget allocation, and leadership has a positive and significant effect on the performance of districts in Garut Regency, both partially and simultaneously. The magnitude of the influence of delegation of authority on sub-district performance reached 0.754 determined by the political will of the district head to delegate part of government authority to the sub-district head, the political will of the district head to make the sub-district the center of community service, regional technical institutions' delegation to delegate part of the technical authority that can be carried out by the district head, budget support and personnel to exercise delegated authority. The magnitude of the effect of budget allocations on a sub-district performance that reaches 0.651 is determined by comprehensive and disciplined, flexibility, predictability, honesty, information, transparency, and accountability. The amount of leadership influence on a sub-district performance that reaches 
0.655 is determined by the guidance and direction given by the sub-district head, the behavior of the sub-district head's relationship with the sub-district apparatus, and the level of readiness of the sub-district apparatus.

\section{REFERENCES}

1. Bachrudin, A., \& Tobing, H. L. (2003). Analisis data untuk penelitian survey dengan menggunakan lisrel 8. Bandung: Jurusan Statistika, FMIPA, UNPAD.

2. Cochran, W. G. (2007). Sampling techniques. John Wiley \& Sons.

3. Ghozali, I. (2008). Structural Equation Modeling: Metode Alternatif dengan Partial Least Square (PLS). Semarang: Badan Penerbit Universitas Diponegoro.

4. Hersey, P., \& Blanchard, K. (1985). Manajemen Perilaku Organisasi. Jakarta: Erlangga.

5. Kaho, J. R. (2002). Prospek Otonomi Daerah di Negara Republik Indonesia. Jakarta: Rajawali Press.

6. Ndraha, T. (2011). Kybernology (Ilmu Pemerintahan Baru). Jakarta: Rineka Cipta.

7. Prawirosentono, S. (1997). Kebijakan Kinerja Karyawan. Yogyakarta: BPFE.

8. Robbins, S. P. (1994). Organization Theory: Structure, Design and Applications. Jakarta: Arcan.

9. Simorangkir, O. P. (2004). Pengantar Lembaga Keuangan Bank Dan Non Bank. Bogor: Ghalia Pustaka.

10. Straus, A., \& Corbin, J. (2007). Dasar-Dasar Penelitian Kualitatif; Tata Langkah dan Teknik-Teknik Teoritisasi Data. Yogyakarta: Pustaka Pelajar.

11. Stoner, J. A. F., \& Wankel, C. (1996). Manajemen. Jakarta: Intermedia.

12. Sugiyono. (2017). Metode Penelitian Kuantitatif, Kualitatif dan RED. Bandung: Alfabeta.

13. Suparmoko, M. (2000). Keuangan Negara Dalam Teori dan Praktek. Yogyakarta: BPFE UGM.

14. Sutarto. (1995).Dasar-dasar Organisasi. Yogyakarta: Gadjah Mada University Press.

15. Terry, G. R. (1960). Office System and Procedurs. Bombay: Taraporevalaa Publishing Industries Privateaa Limited.

16. Wasistiono, S. (2001). Menata Ulang Kelembagaan Kecamatan. Pusat Kajian Pemerintahan STPDN. Penerbit PT Citra Pindo, Bandung.

17. Wasistiono, S. (2004). Modul Optimalisasi Peran dan Fungsi Kecamatan dalam Rangka Meningkatkan Pelayanan Kepada Masyarakat. Bahan Penataran Bagi Camat Seluruh Indonesia, Badan Diklat, Jakarta.

18. Williams, C. (2007). Research methods. Journal of Business E Economics Research $(J B E R), 5(3)$.

19. Yusuf, A. M. (2016). Metode Penelitian Kuantitatif, Kualitatif E Penelitian Gabungan. Jakarta: Prenada Media. 